\title{
The Variables Brand's Relationships and Brand Equity: A Case Study of Mobile Phone Brands Catering to Albanian Consumers
}

\author{
Vjollca Panajoti (Hysi) \\ Head of Marketing Department, Faculty of Economy, University of Tirana, \\ email: vhysi@hotmail.com
}

Irma Shyle

Lecturer, Department of Production and Management, Polytechnic University of Tirana, email: irmitash@yahoo.com

\author{
Mirdaim Axhami \\ Lecturer, Marketing Department, Faculty of Economy, University of Tirana, \\ email: mirdaimaxhami@yahoo.com
}

Doi:10.5901/ajis.2014.v3n3p325

\begin{abstract}
Managers today are aware of the fact that the brand name has become an important asset for the company and is required for their focus on creating brand equity. A strong brand is one that possesses high brand equity. What is evident in all studies is the fact that brand equity is considered as a key factor that can bring the following to the company: higher profits, brand extension opportunities, protection against the competition leading to a strengthening of the consumers purchasing intentions and customer loyalty. Feelings generated by the brands are different from one brand to another and this becomes more evident when customers are emotionally connected only with a certain number of brands. These emotional connections with the brand reflect a specific connection with said brand and thus include feelings toward it which include: attraction, passion and consumer involvement with the brand. The level of customer involvement in this relationship depends on the consumers' perception of the brand as well as the importance that the product brings to the consumer. The power of a brand lies within the mindset of existing or potential customers and through what they have experienced directly or indirectly with the particular brand over a period of time. Brand relationships are not only the main aspects related to brand equity but also are key aspects of the buying process as well as indicators of brand loyalty. Brand relationships consist of thoughts, feelings, perceptions, images, experiences, beliefs and attitudes of consumers associated with the brand. Brand relationships can be described by some subdimensions such as values, personality, and organizational dimensions or some features of a company that gets incorporated within a brand and therefore identify a brand with the company itself. Brand relationships represents a psychological connection with the brand stored in the consciousness of the consumer and also represents aspects of the dimensions referred to tangible or intangible such as attributes, lifestyle, usage etc. The purpose of this paper is to study the relationship that exists between brand relationships and brand equity for the mobile-telephone brands included in the study. Furthermore it will also aim to identify the variables of brand relationships that are considered the most important to Albanian consumers and have significant impact on brand equity.
\end{abstract}

Keywords: brand equity, brand relationships, functional attributes, non-functional attributes.

\section{Brand Relations as Dimension of Brand Equity}

Brand equity is a multidimensional concept and a very complex phenomenon. Keller (2002) focused on two main concepts related to two components: brand awareness and relationships. Aaker $(1991,1996)$ lumped elements associated with brand equity in five categories: perceived quality, brand loyalty, brand awareness, brand relationships and other company-owned asset such as: patents, trademarks, etc. Among these five dimensions of brand, the first four represent customers and assess their reactions to the brand and this enables a better understanding of customers (Barwise 1993; Yoo and Donthu 2001). Numerous studies have focused on measuring brand equity based on the customer. Thus it is evident that strong brand equity means that customers have high awareness of brand name, have a positive image to the brand, perceived that the quality associated with the particular brand is high enough to warrant their loyalty.

Brand relationships are not only the main aspects related to brand equity but also are key aspects of the buying 
process as well as loyalty to the brand (Aaker, 1991, 1992). Brand relationships consist of thoughts, feelings, perceptions, image, experiences, beliefs and attitudes of consumers regarding the particular brand (Kotler and Keller 2006). There are three important dimensions associated with the brand image such as being friendly, powerful and unique. Numerous studies focusing on the relationship of the brand and its impact on building brand equity have highlighted three types of brand relationships (Aaker, 1999; Chen 2001)

$>$ a relationship with the brand as a product (the value),

$>$ a relationship with the brand as a person (brand personality)

$>$ a relationship with the brand as an organization (organizational relationships)

The relationship with the brand as a product include functional and non-functional attributes.

Functional attributes are visible and tangible product features (Keller 1993). So consumers evaluate a brand based on these characteristics associated with the brand. If a brand fails to submit those attributes and characteristics for which it is designed, it is therefore characterized by a low level of brand equity.

Non- functional attributes include symbolic attributes which are invisible or intangible, but for the customer are as important as functional attributes when assessing a brand. Through these dysfunctional attributes the consumer identifies and meets the needs associated with social acceptance or self-esteem. (Keller 1993). We include some of the following as dysfunctional product attributes: social image, perceived value, differentiation, country of origin as well as reliability.

Social image is defined as the consumer perception of the honor and respect for the social group of customers who use the particular brand (Lassaria 1995). All of this has to do with the attributes of a product that a consumer perceives it has, or what other consumers think of the consumers of a certain brand.

Perceived value is defined as the perceived usefulness of the brand associated with its cost and value drawn by the customer based on simultaneous consideration of what was benefited comparatively to the non-use of another product. Consumers choose a brand product by comparing price and all the benefits and values that they benefit from the product and its brand compared to competitors. (Aaker, 1999). The customer is willing to pay a price even higher than compared to normal for a product which is characterized by a high brand equity (Lassaria 1995).

Differentiation is defined as the extent to which consumers perceive that a brand is distinct from competitors and customers believe they are reasonable in purchasing this brand over the competition. (Aaker 1999). A brand can have a premium price if it is perceived as very distinct from competitors (Kapfer 1991). Numerous studies have highlighted the importance of the distinct characteristics of the brand positioning and all this affects the success of a brand.

Country of origin is defined as country, region or state with which consumers perceive a brand association (Thakor and Kohli, 1996). Place of origin of a product as well as brand name are important elements that affect consumer perceptions (Thorelli 1989). Country of origin refers to the country of origin of a company or a product or a place where the product is manufactured. For this reason the country of origin refers to the country of origin of the brand. Lavack and Thakor (2003) assert that the origin of the brand itself is perceived as the most important source of attraction and appeal of the brand. In their study the authors reflect that the perceived country of origin is a powerful agent in determining brand recognition rather than the actual country of origin of the company.

Reliability is defined as the confidence that the customer has with your company, the communications released from the public relations department of the company and everything that done by the company to serve a consumers' interest (Keller \& Aaker, 1992). According to Chaudhuri and Holbrook (2002), reliability is the credibility determine of the brand will support the customer has the ability to perform to mark its stated function. Reliability affects consumers directly in building brand equity (Lassaria 1995) as many cases customers admire the brand of a product just because they belong to a company that has built a positive image towards the consumer (Aaker, 1999).

\section{Brand Relationships and Brand Equity by Aaker 's Model}

According to David Aaker brand relationships deal with categories of assets and liabilities that include everything related to brand remembrance. Aaker states that the dimensions of brand equity relationships usually include the dimensions of the image which are unique to the product class or brand. Brand relationships can be described by some sub-dimensions such as: value, personality, and their organizational dimensions, some company features that are incorporated within a brand to identify the brand with the company. Brand relationships are represented by the psychological connection with brand which is stored in the consciousness of the consumer and also represents dimensions referred to tangible or intangible such as attributes, lifestyle, usage etc.

But brand relationships are also seen as a combination of brand image (i.e. functional and non-functional perceptions), brand attitude (on all brand assessment) and perceived quality (overall superiority trial). Relations consist of brand image in functional and symbolic beliefs of the product categories which are brand specific extensions and their 
measurement should focus on the unique features of the brand specific categories. Attitudes towards the brand consist of a general assessment of the brand. The perceived quality is related to customer judgments about superiority or excellent quality of the brand in general. This highlights the argument that strong brands can add value to consumer purchases. Brand relationships are important for the companies and for its consumers. Companies use brands to differentiate, position and expand the brand, to create positive attitudes and feelings towards it, and to suggest attributes or benefits from the purchase or use of a specific brand. Consumers use brand relationships to assist in arranging, organizing and reliving information stored within their memory and use it in the purchase making decision.

This article will use the model built by Aaker (1991), which is among the most frequently used by a great deal of the research and current studies to measure brand equity. This model has been tested empirically in a number of previous studies (Atılgan, Aksoy and Akinci, 2005 , Kim and Kim 2004 ; Yoo, Donthu and Lee, 2000). Through Aaker 's model this study will retest the measurement of brand equity based on the products selected by Albanian consumers.

If a brand clearly positions itself through one or more relationships, it will be difficult for the competition to claim the lead on aspects implied by these relationships, which can lead to barriers to entry for competitors.

\section{Explorative Pursuit}

Choosing brands of mobile phones was based on a preliminary test of 20 individuals. The selection of individuals was random. Each individual was asked to specify four of most popular brands of cellular phones, sought after or ideal. For each of the brands selected individuals were asked to give their assessment on a scale of 1 to 5 . Results were obtained for the following brands: iPhone (Apple), Nokia, Blackberry, Samsung Galaxy, as the four most popular brands to be keen on by the surveyed customers. Participants in this study were asked to determine the degree of importance of each element of brand relationships.

Prior to the participation in questionnaire, a short presentation regarding the research that took place was distributed to inform the participant regarding the questionnaire and its purpose. Persons who assisted with the delivery and monitoring of the questionnaires were marketing students with sufficient knowledge regarding the elements of the brand.

The assessment rate used was according to the 1-5 Likert scale, under which the evaluation was based on the scale: 1 - not at all to 5 - very. The reason that we refer to 5 - tiered evaluation of Likerts' is because it is the most frequently used scale in studies made in the measurement of brand equity based on the customer ( Washburn and Plank, 2002).

Malhotra (1999) suggests that the minimum sample for research should be at least 200. We consulted with experts on the methodology for a $95 \%$ coverage of the population. For this reason around 320 sample questionnaires should have been built. To supplement any incorrect or blank questionnaires around 370 sets of questionnaires were distributed through which we managed to gather 356 questionnaires, 12 of which were invalid. Thus, the number of valid questionnaires for survey and data analysis was 344 questionnaires.

Sample / selection was aimed at interviewing people over the age of 18 . This category was chosen because individuals over the age of 18 have their own income and make their own choice of brands for products they buy or want to buy. It was observed that the highest percentage of respondents belonged to the age group 18 to 25 years old (64 \% or 221 individuals) mainly with a Bachelors' Degree (53\% or 183 individuals). Of 344 individuals interviewed: $43 \%$ ( $n=$ 147) were employed and $57 \%(n=197)$ were unemployed; Male $53 \%(n=182)$, Female $47 \%(n=162)$. The 344 respondents chose the following brands of phones: $36 \%$ - Nokia $(n=123), 29 \%$ - i-Phone (Apple) $(n=101), 26 \%$ Samsung Galaxy $(n=90), 9 \%$ - Blackberry $(n=30)$.

Data analysis was conducted in SPSS 17.0 statistical software. Factorial analysis was used to view the underlying determinant variables of a factor, their structure. Statistically significant difference of a set of variables associated with capital, demographic variables in terms of customer and non-customer brand

was tested by logistic regression analysis.

Pearson chi square analysis was used to make hypothesis testing but also to understand the meaning or connection variables with dimensions of brand equity. Having earlier settled that an error rate of $a=5 \%$ and a $95 \%$ confidence level, using chi square test we believe that we will have a significant and important link in those instances when the test results to $p$ - value should be less than $\alpha$.

Factorial analysis was used to find factors among the study variables by reducing the number of variables and grouping variables with similar characteristics together.

Through the use of the Structural equation models (SEMs) we could see the presence of multicollinearity. For the evaluation of the model the following indicators were used: Goodness -of - Fit Index (GFI) which measures the relative 
quantity of variance - covariance, Comparative Fit Index (CFI) that takes into account the size of the sample, and Root Mean Square Error of Approximation (RMSE) that explains how well the selected parameter values approximate with the Matrix covariance of the population.

We discovered the following bond between the sample population and the brand equity questions:

1. Even if another brand has the same features as $X$ marks I still prefer to buy brand $X$.

2. If another brand is not different from brand $X$, then buying brand $X$ is a wiser purchase.

3. The brand $X$ is more than a product of me.

Relying again on chi -square analysis and monitoring the $p$ - values to see which elements or sub-dimensions of brand relations we see which one of the three questions about brand equity are the most significant. In this way for the product phone we recorded the following to determine the most important links.

There seems to be a significant relation between the variables of the mobile brand relationship score all questions Item $\mathrm{X}$ and $\mathrm{X}$ brand equity as follows:

$>$ This brand is innovative - Even if another brand has the same features as brand $X$, I will buy brand $X(p=$ $0.045)$

$>$ This brand is secure and safe to use - even if another brand is not different from brand $X$, buying brand $X$ is smart $(p=0.015)$

$>$ This brand is not just a product for me - Even if another brand has the same features as brand $X, I$ will buy brand $X(p=0.003)$; Even if another brand is not different from brand $X$, buying brand $X$ is smart $(p=0.000)$; brand $X$ is more than a product to me $(p=0.000)$.

$>$ This brand has personality - Even if another brand has the same features as brand $X, I$ will buy brand $X(p=$ $0.047)$; Even if another brand is not different from brand $X$, buying brand $X$ is wise $(p=0.003)$; Brand $X$ is more than a product to me $(p=0.000)$.

$>\quad$ I have a clear image of the type of person who buys - Brand X is more than a product to me $(p=0.000)$

It also shows a strong link between three brand equity questions and variables as follows:

$>$ I appreciate and admire people who use this brand

$>\mathrm{It}$ is interesting brand

$>$ This is exciting brand

This is the best brand to buy

$>$ It is ethical brand

$>$ This brand coincides with my style of life

$>$ I believe the company that produces the brand

$>$ I enjoy the company that produces the brand

$>$ The company that produces the brand is innovative

Based on the answers given factorial analysis was used to see the connection of group variables with three brand equity questions. Based on KMO test, as has a value higher than 0.8 (0885 for mobile) shows a very good rating for the use of factorial analysis.

From this analysis, "Even if another brand has the same features as brand $X, I$ will buy brand $X$ " and "Even if another brand is not different from brand $X$, buying brand $X$ is wise" have a coefficient of less than 0.4 .

Based on chi -square test variable "I have a clear image of the type of person who buys" with "Even if another brand has the same features as brand X, I will buy brand X" and "Even if a brand the other is not different from brand X, $X$ is buying wise" no statistically significant link.

Also variable "This brand is safe and safe for use" with "Even if another brand has the same features as X marks I will buy brand X" and "X is more than a product of me" not there is a statistically significant link. Variable "this brand is innovative" and "Even if another brand is not different from brand X, buying brand X is the wise" do not have a statistically significant relation.

Based on the correlation coefficients of all variables as brand relationship for mobile brands, positive impact on brand equity variable, where most of them to a large extent significance ( $p$ - value $<5 \%)$. 


\begin{tabular}{|l|c|c|}
\hline \multicolumn{1}{|c|}{ Question } & & \\
\hline X11 This brand is innovative & .676 & Kaiser-Meyer-Olkin Measure of Sampling Adequacy=.885 \\
\hline X12 This brand is safe and harmless to use & .577 & Bartlett's Test of Sphericity \\
\hline X13 This brand is not simply a product of me & .535 & Approx. Chi-Square=1499.703 \\
\hline X14 This brand has personality & .566 & p-value=0.000 \\
\hline X15 I have a clear image of the type of person who buys & .488 & \\
\hline X16 I appreciate and admire people who use this brand & .612 & \\
\hline X17 This brand is interesting & .510 & \\
\hline X18 This brand is exciting & .458 & \\
\hline X19 This is the best brand to buy & .563 & \\
\hline X20 This brand is ethical & .427 & \\
\hline X21 This brand matches my style of life & .584 & \\
\hline X22 I believe the company that produces the brand & .551 & \\
\hline X23 I enjoy the company that produces the brand & .559 & \\
\hline X24 The company that produces the brand is innovative & .721 & \\
\hline
\end{tabular}

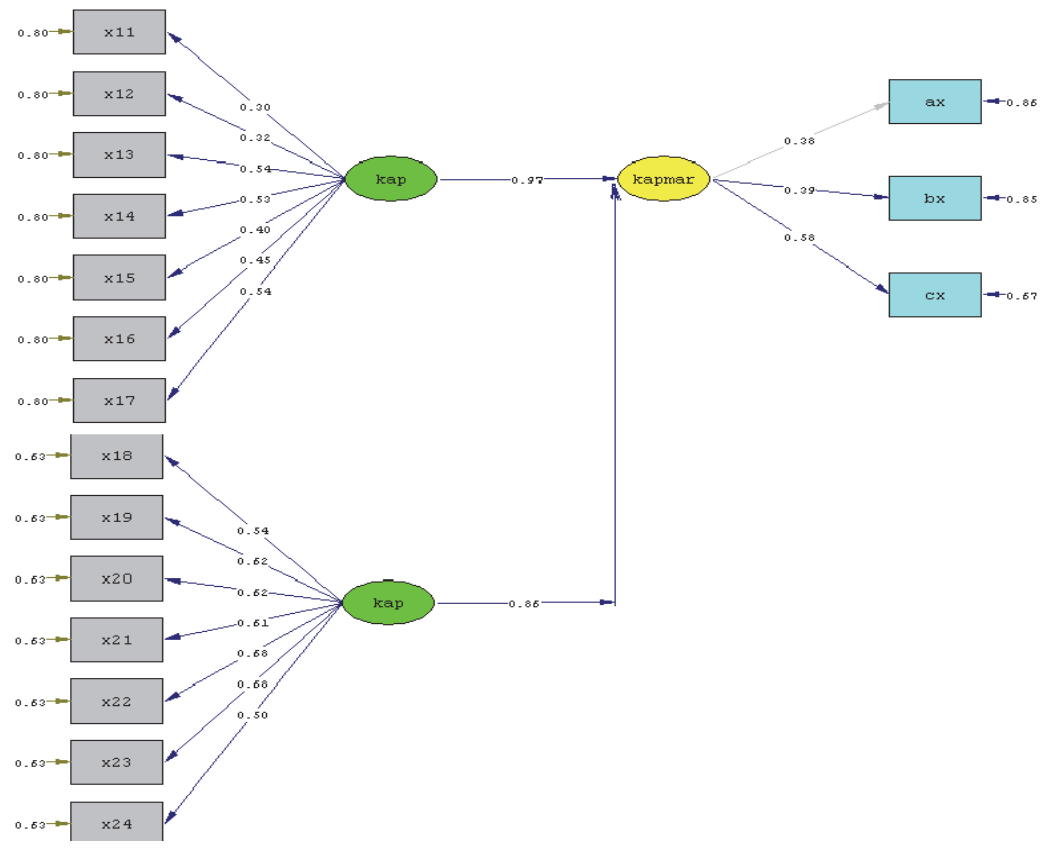

Based on factor analysis, correlation and SEM model, it is clear that the variables that most affect the brand equity of the phones are not the same and that in terms of weight or degree of importance they have on brand equity.

In summary, variable dimensions of brand equity and brand awareness respectively, according to their degree of importance of brand equity, for mobile phone are as follows: 
Questions about the relationships of the elements of the mobile brand

\begin{tabular}{|l|c|}
\hline X22 I believe the company that produces the brand & 0.68 \\
\hline X23 I enjoy the company that produces the brand & 0.68 \\
\hline X19 This is the best brand to buy & 0.62 \\
\hline X20 This brand is ethical & 0.62 \\
\hline X21 This brand matches my style of life & 0.61 \\
\hline X13 This brand is not simply a product of me & 0.54 \\
\hline X17 This brand is interesting & 0.54 \\
\hline X18 This brand is exciting & 0.54 \\
\hline X14 This brand has personality & 0.53 \\
\hline X24 is the company that produces innovative brand & 0.50 \\
\hline X16 I appreciate and admire people who use this brand & 0.45 \\
\hline X15 I have a clear image of the type of person who buys this brand & 0.40 \\
\hline X12 This brand is safe and harmless to use & 0.32 \\
\hline X11 This brand is innovative & 0.30 \\
\hline
\end{tabular}

So this dimension for consumers considered most important: trust the company that produces the brand, the consent of the Company by the customer, trust that bought the brand worth, as well as the fact that it is ethical brand.

For mobile brands included in the study, considered unimportant or with a low coefficient of importance of brand equity variables associated with: the image of people who buy, safety and the safety of use and the fact that this brand is innovative.

\section{Conclusions and Recommendations}

Relations with the brand as product include functional and non-functional product attributes (Aaker, 1999; Chen 2001).

Details of the research show that consumers are very interested in the functional product attributes and the product being particularly safe and harmless to use shown by the $54 \%$ choice of mobile brands. Among the dysfunctional attributes that customers consider important for brands, is trust and consensus with the company that produces the brand. Customers, due to strong association with some operational attributes, consider the particular brand of phone they chose to be the best one to buy as it satisfies their consideration on the brand being ethical, interesting and with personality. They state that brand $X$ is the better as it corresponds with their lifestyle and not because it is the choice of other consumers. In this way it seems like a very unique customer relationships with mobile brand $X$ as it was chosen without influence by other people who use these brands, furthermore consumers did not express any high degree of appreciation or admiration for people who use this brand.

The data show that the mobile brands are not just a product for consumers.

In the case of the mobile brand $\mathrm{X}$ brand relationships positively impact brand equity $\mathrm{X}$, and the extent of this impact is high in value 0.92 .

From the data, for the mobile brands, it is clear that the variables that influence this impact are some of the nonfunctional variables associated with: reliability and consent of the producer of the brand, the perceived value of the brand (the better to buy), compliance with lifestyle as well as a number of elements that relate to the personality of the brand. Despite the positive impact that these variables have, the extent of their influence is not very high.

For this reason the recommendation in connection with this conclusion is that manufacturing companies should care more about the personality of the brand but also in better understanding the personality of consumers who prefer to buy their brands.

In this way the company can help customers have a clear image of the type of person who buys this brand.

Companies should be looking more to understand whether the consumers buy brands $X$ just to feel good about themselves or to better their current or ideal image. They should inform and persuade consumers that their brands $X$ are not only distinct and innovative, especially since this paper shows that a customers' relationships with the brand as innovative, secure and safe to be used have a low impact on brand equity $X$. 


\section{References}

Aaker, D. (1991), Managing Brand Equity. Capitalizing on the Value of a Brand Name, Free press, New York

Aaker, D. (1996), "Measuring Brand Equity, Across Products and Markets" California Management Review, 38(3), pp.102-120

Allaway, A. W., Huddleston, P., Whipple, J and Ellinger, A.E. (2011), Customer-based brand equity, equity drivers and customer loyalty in the supermarket industry", Journal of Product \&Brand Management, Vol. 20, No. 3, pp. 190-204

Barwise, P., Higson, C., Likierman and A., Marsh, P (1989), Accounting for Brands, The London Business School and the Institute of Chartered Accountants in England and Males, London

Biel, Alexander L.(1993), Converting Image into Equity. In: D. Aaker, and A. Biel (Eds.), Brand Equity and Advertising. Hillsdale: Lawrence Erlbaum Associates

Cobb-Walgren, C, J., Ruble C.A \& Donthu N. (1995), "Brand equity, brand preference and purchase intent." Journal of Advertising 24, 25-40

Gilmore, James H. and B. Joseph Pine II (2007), Authenticity: What Consumers Really Want. Boston: Harvard Business School Press

Kapferer, J.A (1997), Strategic Brand Management: Creating and sustaining brand equity long term, Second Edition, Kogan Page, London

Keller, K (2008) Strategic Brand Management: Building, Measuring, and Managing Brand Equity, 3-rd edition, New Jersey: Pearson Education, Inc.

Kotler, P. and Keller, K.L (2006), Marketing Management, Pearson Education, Upper Saddle River, NJ

Lassar, W., Mittal, B and Sharma, A (1995). "Measuring Customer-Based Brand Equity", Journal of Consumer Marketing, Vol. 12, No 4, pp. 11-19

Malhotra, N.K, Peterson, M and Kleiser, S.B "Marketing Research: A State of the Art Review and Directions for the Twenty-First Century". Journal of the Academy of Marketing Science, Vol. 27, No 2, pp. 160-183

Park,C. Deborah J. MacInnis, Joseph Priester, Andreas B. Eisingerich, and Dawn lacobucci (2010), "Brand Attachment and Brand Attitude Strength: Conceptual and Empirical Differentiation of Two Critical Brand Equity Drivers," Journal of Marketing, 74 (6), 1 17

Reilly, R.F and Schweihs, R.P (1999), Valuing Intangible Assets, McGraw Hill, New York

Wood, L. (2000). Brands and brand equity: definition and management. Management Decision, 38 (9), 622-9

Yoo, B and Donthu, N (2001), "Developing and validating a multidimensional consumer-based brand equity scale", Journal of Business Research, 52, 1-14 